Supporting Information to Accompany “Triphenylamine Derivatives with Large TwoPhoton Cross Section"

Wen Jun Yang, Dae Young Kim, Chang Ho Kim, Mi-Yun Jeong, Seung Kyu Lee, Seung-Joon Jeon,* and Bong Rae Cho*

Molecular Opto-Electronics Laboratory, Department of Chemistry and Center for Electro- and Photo-Responsive Molecules, Korea University, 1-Anamdong, Seoul 136-701, Korea, chobr@korea.ac.kr

\title{
Synthesis of 1-3.
}

Compound 1a was prepared by the literature procedure. ${ }^{1}$ Synthesis of other compounds is described below.

$N, N, N$-Tris-[(4-cyanostyryl)phenyl]amine (1b). LDA (1.5 M in cyclohexane) $(0.85 \mathrm{~mL}, 1.3$ mmol) was added dropwise to a stirred solution of (4'-methylbiphenyl-4-yl)methylphosphonic acid diethyl ester $(0.39 \mathrm{~g}, 1.2 \mathrm{mmol})$ in anhydrous THF $(15 \mathrm{~mL})$ at $-78{ }^{\circ} \mathrm{C}$ under argon. The mixture was stirred for $1 \mathrm{~h}$ and then $N, N, N$-tris(4-formylphenyl)amine $(0.1 \mathrm{~g}, 0.3 \mathrm{mmol})^{2}$ in THF $(3.0 \mathrm{~mL})$ was added dropwise over a period of $5 \mathrm{~min}$. After the mixture was stirred for $2 \mathrm{~h}$ at $-78^{\circ} \mathrm{C}$ and for $6 \mathrm{~h}$ at room temperature, $1.0 \mathrm{~mL}$ of water was added and the solvent was evaporated. The residue was dissolved into $\mathrm{CH}_{2} \mathrm{Cl}_{2}$ and washed several times with water. The product was purified by a column chromatography on silica gel using hexane/ $\mathrm{CH}_{2} \mathrm{Cl}_{2}(1 / 2)$ as the eluent. Yield $0.21 \mathrm{~g}(63 \%) ; \mathrm{Mp}: 148$ ${ }^{\circ} \mathrm{C} ;{ }^{1} \mathrm{H}$ NMR (300 MHz, $\left.\mathrm{CDCl}_{3}\right): \delta 7.63(\mathrm{~d}, J=9.0 \mathrm{~Hz}, 6 \mathrm{H}), 7.57$ (d, $\left.J=9.0 \mathrm{~Hz}, 6 \mathrm{H}\right), 7.45(\mathrm{~d}, J=$ $9.0 \mathrm{~Hz}, 6 \mathrm{H}), 7.18(\mathrm{~d}, J=15 \mathrm{~Hz}, 3 \mathrm{H}), 7.13(\mathrm{~d}, J=9.0 \mathrm{~Hz}, 6 \mathrm{H}), 7.01(\mathrm{~d}, J=15 \mathrm{~Hz}, 3 \mathrm{H}) .{ }^{13} \mathrm{C}$ NMR $(75$ $\left.\mathrm{MHz}, \mathrm{CDCl}_{3}, \mathrm{ppm}\right): \delta 140.8,139.2,131.9,129.3,127.1,126.9,124.9,124.8,121.4,116.5,111.7$ Calcd for $\mathrm{C}_{45} \mathrm{H}_{30} \mathrm{~N}_{4}$ : C, 86.24; H, 4.82; N, 8.94. Found: C, 86.24; H, 4.82; N, 8.92.

Tris\{4-[4-(2,2-dicyanovinyl)styryl]phenyl\}amine (1c). To a solution of tris-[4-( $p$ formylstyryl)phenyl]amine ( $350 \mathrm{mg}, 0.55 \mathrm{mmol})$ in $20 \mathrm{~mL}$ of anhydrous pyridine, $1.5 \mathrm{~g}$ molecular sieves (3 $\AA$ ), one crystal of $\mathrm{NH}_{4} \mathrm{OAc}, 8$ drops of $\mathrm{HOAc}$ and $150 \mathrm{mg}$ of $\mathrm{CH}_{2}(\mathrm{CN})_{2}(2.3 \mathrm{mmol})$ were added. The mixture was stirred at RT for $5 \mathrm{~h}$ and the solvent was removed under reduced pressure. 
The residue was dissolved in $\mathrm{CH}_{2} \mathrm{Cl}_{2}$ and the organic layer washed with water and dried over anhydrous $\mathrm{Na}_{2} \mathrm{SO}_{4}$. Chromatography $\left(\mathrm{SiO}_{2}, \mathrm{CHCl}_{3}\right.$ /ethyl acetate $\left.=40 / 1\right)$ and recrystallization from $\mathrm{CHCl}_{3} / \mathrm{EtOH}$ afforded $270 \mathrm{mg}(63 \%)$ of brown solid. Mp 286-288 ${ }^{\circ} \mathrm{C} .{ }^{1} \mathrm{H} \mathrm{NMR}\left(300 \mathrm{MHz}, \mathrm{CDCl}_{3}\right.$, ppm): $\delta 7.91(\mathrm{~d}, J=9.0 \mathrm{~Hz}, 6 \mathrm{H}), 7.71(\mathrm{~s}, 3 \mathrm{H}), 7.62(\mathrm{~d}, J=9.0 \mathrm{~Hz}, 6 \mathrm{H}), 7.48(\mathrm{~d}, J=9.0 \mathrm{~Hz}, 6 \mathrm{H})$, $7.28(\mathrm{~d}, J=15 \mathrm{~Hz}, 3 \mathrm{H}), 7.16(\mathrm{~d}, J=9.0 \mathrm{~Hz}, 6 \mathrm{H}), 7.06(\mathrm{~d}, J=15 \mathrm{~Hz}, 3 \mathrm{H})$. Anal. Calcd for $\mathrm{C}_{54} \mathrm{H}_{33} \mathrm{~N}_{7}$ : C, 83.16; H, 4.26; N, 12.57. Found: C, 83.15; H, 4.26; N, 12.47.

Tris[4-(4-\{4-[5-(p-tert-butylphenyl)-1,3,4-oxadiazol-2-yl]styryl $\}$ styryl)phenyl]amine (2a). Tris[4(p-bromostyryl)phenyl]amine $(0.12 \mathrm{~g}, 0.16 \mathrm{mmol}), 4$-[5-(p-tert-butylphenyl)-1,3,4-oxadiazol-2yl]styrene $(0.20 \mathrm{~g}, 0.63 \mathrm{mmol}),{ }^{1} \mathrm{Pd}(\mathrm{OAc})_{2}(5.0 \mathrm{mg}, 0.016 \mathrm{mmol}), \mathrm{P}(\mathrm{o}-\text { tolyl })_{3}(0.380 \mathrm{mg}, 0.12 \mathrm{mmol})$, $\mathrm{Et}_{3} \mathrm{~N}(1.0 \mathrm{~mL}), \mathrm{MeCN}(1.0 \mathrm{~mL})$ were added to a pressure tube with a plunger valve and a magnetic bar under protecting of argon. The resulting mixture was refluxed for $24 \mathrm{~h}$ and then cooled to room temperature. The mixture was poured with vigorous stirring into $50 \mathrm{~mL}$ of methanol. The precipitate formed was collected on a filter and washed thoroughly with methanol, and crude product was recrystallized from methanol and then separated by column chromatography on silica gel using $\mathrm{CHCl}_{3}$ /ethyl acetate $(10 / 1)$ as the eluent (10:1). Yield $76 \mathrm{mg}(33 \%)$; Mp 284-286 ${ }^{\circ} \mathrm{C} ;{ }^{1} \mathrm{H}$ NMR $(300$ $\left.\mathrm{MHz}, \mathrm{CDCl}_{3}, \mathrm{ppm}\right): \delta 8.14(\mathrm{~d}, J=9.0 \mathrm{~Hz}, 6 \mathrm{H}), 8.08(\mathrm{~d}, J=9.0 \mathrm{~Hz}, 6 \mathrm{H}), 7.68(\mathrm{~d}, J=9.0 \mathrm{~Hz}, 6 \mathrm{H})$, $7.57(\mathrm{~d}, J=9.0 \mathrm{~Hz}, 6 \mathrm{H}), 7.55(\mathrm{~m}, 12 \mathrm{H}), 7.46(\mathrm{~d}, J=9.0 \mathrm{~Hz}, 6 \mathrm{H}), 7.25(\mathrm{~d}, J=15 \mathrm{~Hz}, 3 \mathrm{H}), 7.16(\mathrm{~d}, J$ $=18.0 \mathrm{~Hz}, 3 \mathrm{H}), 7.15(\mathrm{~d}, J=9.0 \mathrm{~Hz}, 6 \mathrm{H}), 7.14(\mathrm{~d}, J=15.0 \mathrm{~Hz}, 3 \mathrm{H}), 7.05(\mathrm{~d}, J=18 \mathrm{~Hz}, 3 \mathrm{H}), 1.40(\mathrm{~s}$, 27H). Anal. Calcd for $\mathrm{C}_{102} \mathrm{H}_{87} \mathrm{~N}_{7} \mathrm{O}_{3}$ : C, 83.98; H, 6.01; N, 6.72. Found: C, 83.93; H, 6.06; N, 6.80.

$N, N, N$-Tris $\{4-[4-(p$-cyanostyryl)styryl]phenyl $\}$ amine (2b). Prepared by the same procedure as described for $\mathbf{1 b}$ except that $N, N, N$-tris[4-(4-formylstyryl)phenyl]amine and ( $p$ cyanobenzyl)phosphonic acid diethyl ester were used. Chromatography $\left(\mathrm{SiO}_{2}, \mathrm{CH}_{2} \mathrm{Cl}_{2} /\right.$ hexane $\left.=2 / 1\right)$, Yield, $40 \%$; Mp $192{ }^{\circ} \mathrm{C} ;{ }^{1} \mathrm{H}$ NMR $\left(300 \mathrm{MHz}, \mathrm{CDCl}_{3}\right): \delta 7.64(\mathrm{~d}, J=9.0 \mathrm{~Hz}, 6 \mathrm{H}), 7.58(\mathrm{~d}, J=9.0$ $\mathrm{Hz}, 6 \mathrm{H}), 7.52(\mathrm{~m}, 12 \mathrm{H}), 7.44(\mathrm{~d}, J=9.0 \mathrm{~Hz}, 6 \mathrm{H}), 7.22(\mathrm{~d}, J=15 \mathrm{~Hz}, 3 \mathrm{H}), 7.12(\mathrm{~d}, J=9.0 \mathrm{~Hz}, 6 \mathrm{H})$, $7.10(\mathrm{~d}, J=15 \mathrm{~Hz}, 3 \mathrm{H}), 7.09(\mathrm{~d}, J=15 \mathrm{~Hz}, 3 \mathrm{H}), 7.03(\mathrm{~d}, J=15 \mathrm{~Hz}, 3 \mathrm{H}) .{ }^{13} \mathrm{C} \mathrm{NMR}\left(75 \mathrm{MHz}, \mathrm{CDCl}_{3}\right.$, ppm): $\delta 146.6,141.7,137.8,135.2,132.4,132.0,131.8,128.5,127.5,127.2,126.7,126.6,126.5$. 126.3, 124.2, 119.0, 110.4. Calcd for $\mathrm{C}_{69} \mathrm{H}_{48} \mathrm{~N}_{4}: \mathrm{C}, 88.81 ; \mathrm{H}, 5.18 ; \mathrm{N}, 6.00$. Found: C, 88.87; H, 
5.12; N, 5.94 .

$N, N, N$-Tris(4-\{4-[1-cyano-1-(p-cyanophenyl)vinyl-2yl]styryl\}phenyl)amine (3b). $t$-BuOK (11 mg, $0.10 \mathrm{mmol}$ ) was added to a solution of $N, N, N$-tris(4-formylphenyl)amine (80 $\mathrm{mg}, 0.24 \mathrm{mmol})$ and (p-cyanophenyl)acetonotrile $(170 \mathrm{mg}, 1.2 \mathrm{mmol})$ in $\mathrm{EtOH} /$ benzene $(2 / 1,150 \mathrm{~mL})$, and the resulting solution was refluxed for $8 \mathrm{~h}$. The solvent was removed on a rotary evaporator, and the residue was separated by column chromatography on silica gel using $\mathrm{CHCl}_{3}$ /ethyl acetate $(30: 1)$ as the eluent. Yield 36 mg (21\%); Mp: 200-202 ${ }^{\circ} \mathrm{C} ;{ }^{1} \mathrm{H}$ NMR (300 MHz, $\left.\mathrm{CDCl}_{3}, \mathrm{ppm}\right): \delta 7.94(\mathrm{~d}, J=9.0 \mathrm{~Hz}, 6 \mathrm{H})$, $7.80(\mathrm{~d}, J=9.0 \mathrm{~Hz}, 6 \mathrm{H}), 7.74(\mathrm{~d}, J=9.0,6 \mathrm{H}), 7.62(\mathrm{~d}, J=9.0 \mathrm{~Hz}, 6 \mathrm{H}), 7.56(\mathrm{~s}, 3 \mathrm{H}), 7.48(\mathrm{~d}, J=9.0$ $\mathrm{Hz}, 6 \mathrm{H}), 7.22(\mathrm{~d}, J=15 \mathrm{~Hz}, 3 \mathrm{H}), 7.14(\mathrm{~d}, J=9.0 \mathrm{~Hz}, 6 \mathrm{H}), 7.06(\mathrm{~d}, J=15 \mathrm{~Hz}, 3 \mathrm{H}) .{ }^{13} \mathrm{C} \mathrm{NMR}(75$ $\left.\mathrm{MHz}, \mathrm{CDCl}_{3}, \mathrm{ppm}\right): \delta 147.26,144.38,141.10,139.18,133.05,132.06,132.03,130.84,130.52$, $128.18,127.11,126.63,126.45,124.60,118.48,117.70,112.72,108.87$. Anal. Calcd for $\mathrm{C}_{72} \mathrm{H}_{45} \mathrm{~N}_{7}$ : C, 85.78; H, 4.50; N, 9.73. Found: C, 85.72; H, 4.58; N, 9.70.

$N, N, N$-Tris(4-(1-cyano-1-(4-cyanophenyl)vinyl)phenyl)amine (3d). Prepared by the same procedure as described for $\mathbf{3 b}$ except that $N, N, N$-tris(4-formylstyrylphenyl)amine and (4'methylbiphenyl-4-yl)acetonitrile ${ }^{3}$ were used. The product was purified by a column chromatography on a silca gel using $\mathrm{CHCl}_{3}$ /ethyl acetate (30:1) as the eluent. Yield, $35 \%$; Mp 230-232 ${ }^{\circ} \mathrm{C}$; ${ }^{1} \mathrm{H}$ NMR $\left(300 \mathrm{MHz}, \mathrm{CDCl}_{3}\right): \delta 7.91(\mathrm{~d}, J=9.0 \mathrm{~Hz}, 6 \mathrm{H}), 7.73(\mathrm{~d}, J=9.0 \mathrm{~Hz}, 6 \mathrm{H}), 7.65(\mathrm{~d}, J=9.0 \mathrm{~Hz}, 6 \mathrm{H})$, $7.58(\mathrm{~d}, J=9.0 \mathrm{~Hz}, 6 \mathrm{H}), 7.53(\mathrm{~s}, 3 \mathrm{H}), 7.52(\mathrm{~d}, J=9.0 \mathrm{~Hz}, 6 \mathrm{H}), 7.46(\mathrm{~d}, J=9.0 \mathrm{~Hz}, 6 \mathrm{H}), 7.27(\mathrm{~d}, J=$ $9.0 \mathrm{~Hz}, 6 \mathrm{H}), 7.18(\mathrm{~d}, J=15 \mathrm{~Hz}, 3 \mathrm{H}), 7.14(\mathrm{~d}, J=9.0 \mathrm{~Hz}, 6 \mathrm{H}), 7.05(\mathrm{~d}, J=15 \mathrm{~Hz}, 3 \mathrm{H}), 2.41(\mathrm{~s}, 12 \mathrm{H})$.

${ }^{13} \mathrm{C} \mathrm{NMR}\left(75 \mathrm{MHz}, \mathrm{CDCl}_{3}, \mathrm{ppm}\right): \delta 147.12,142.02,141.24,139.99,137.93,137.25,133.39,132.87$, $132.14,130.10,130.03,129.84,128.03,127.60,127.04,126.95,126.66,126.47,124.53,118.44$, 110.44, 21.20. Anal. Calcd for $\mathrm{C}_{90} \mathrm{H}_{66} \mathrm{~N}_{4}: \mathrm{C}, 89.82 ; \mathrm{H}, 5.53 ; \mathrm{N}, 4.66$. Found: C, 89.81; H, 5.41; N, 4.64 . 


\section{Fluorescence spectra of 1-3.}

The fluorescence spectra of $\mathbf{1 - 3}$ in toluene are depicted in Figure S1.

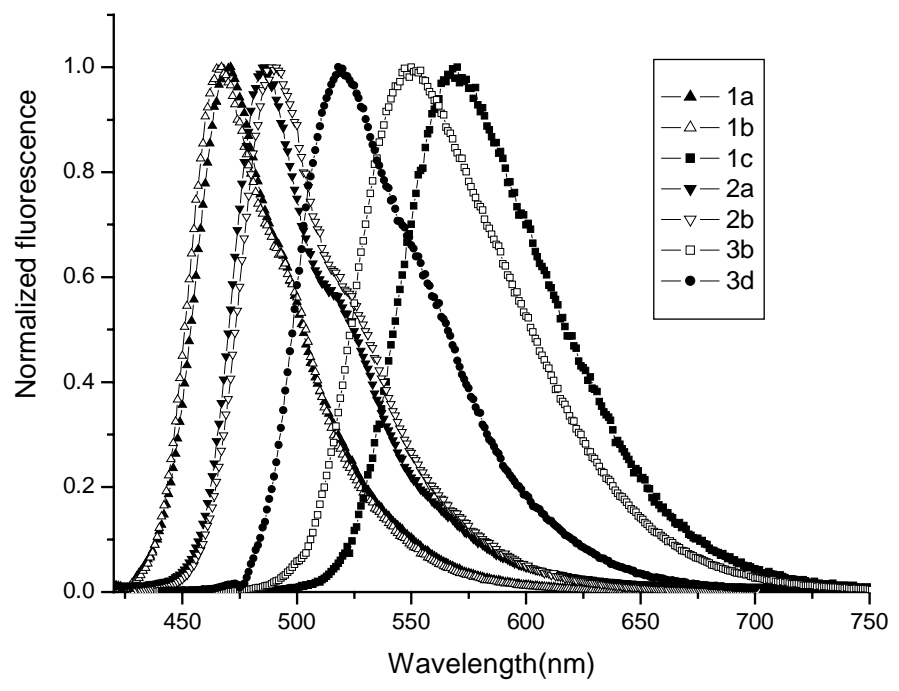

Figure S1. Fluorescence spectra of $\mathbf{1}-\mathbf{3}$ in toluene.

\section{Measurement of two-photon cross section by the two-photon induced fluorescence method.}

The two-photon absorption cross-section of the octupolar compounds has been measured with the two-photon-induced fluorescence method by using the nano-second laser pulses as described., Samples were dissolved in toluene at concentrations of $5.0 \times 10^{-6} \mathrm{M}$ and the two-photon induced fluorescence intensity was measured at $750-1050 \mathrm{~nm}$ by using fluorescein and rhodamine $\mathrm{B}$ as the reference.

\section{Measurement of two-photon cross section by the femtosecond z-scan method.}

It is well established that the beam-intensity change along the propagation direction (z axis) can be described as

$$
I(z)=\frac{I(0) \exp (-\alpha z)}{1+\beta z I(0)}
$$

where $\alpha$ is the attenuation coefficient that is due to linear absorption and scattering, $\beta$ is the nonlinear absorption coefficient that is due to TPA, and $\mathrm{z}$ is the sample thickness, respectively. When the linear absorption is small, $\alpha z$ " 1 , the transmittance of the nonlinear medium can be written as 


$$
T(z)=I(z) / I(0)=\frac{\exp (-\alpha z)}{1+\beta z I(0)} \cong \frac{1}{1+\beta z I(0)}, \quad \alpha \approx 0
$$

where $I(0)$ is the input intensity $I_{0}$.

The relationship between $\beta$ and TPA cross section $\delta_{2}$ (in units of $\mathrm{cm}^{4} / \mathrm{GW}$ ) of the solute molecules can be expressed as,

$$
\beta=\delta_{2} N_{0}=\delta_{2} N_{A} d_{0} \times 10^{-3}
$$

where $N_{A}$ and $d_{o}$ are the Avogadro number and the mole concentration of the solute molecule, respectively. Substituting Eq.(3) into Eq.(2) and rearranging,

$$
1 / T(L)^{-1}=\delta_{2} N_{A} \times 10^{-3} L d_{0} I_{o}
$$

where $T(L)$ is the transmittance at the sample thickness $L$ of the nonlinear medium. Eq.(4) indicates that the TPA cross section $\delta_{2}$ can be measured from the slopes of the plots of $\left(1 / T(L)^{-1)}\right.$ against $I_{o}$ and $d_{o}$.

The open aperture z-scan experiment has been conducted by using the essentially the same experimental setup and procedure as described. ${ }^{6,7}$ A linearly polarized $800 \mathrm{~nm}$ fs pulsed laser beam was used as the source. A mode-locked Titanium:Sapphire laser (Mira900-F, Coherent) produced single Gaussian $180 \mathrm{fs}$ pulse $(800 \mathrm{~nm})$. The pulse was amplified by Nd:YLF laser (Titan, Quantronix, pulse width $\approx 200 \mathrm{fs}(\mathrm{FWHM})$, repetition rate $=1 \mathrm{kHz}$ ), so that the laser power would be approx. 0.9 $\sim 1 \mathrm{~W}$ at the wavelength of $800 \mathrm{~nm}$, and reduced to several $\mu \mathrm{W}$ by using a variable neutral density filter. After passing through an $\mathrm{f}=30.5 \mathrm{~cm}$ lens, this laser beam was focused $\left(\omega_{0}=3.88 \times 10^{-3} \mathrm{~cm}\right)$ and passed through a $2.0 \mathrm{~mm}$ glass cell filled with the sample solution $\left[1.2 \times 10^{-3} \mathrm{M} \sim 0.9 \times 10^{-4} \mathrm{M}\right.$ in THF]. The transmitted laser beam from the sample cell was detected, while changing position of the sample cell along the beam direction (z-axis), by using a photo diode. Input intensity ranged from $300 \mu \mathrm{W}$ to $600 \mu \mathrm{W}$, which corresponds to the peak irradiance $I_{o}$ ranging from 30.7 to $61.4 \mathrm{GW} / \mathrm{cm}^{2}$ at the focus, respectively. The peak irradiance $I_{o}$ was calculated with the last pulse width $\approx 233 \mathrm{fs}$ at sample. The last pulse width was measured with pump $(800 \mathrm{~nm})$-probe $(800 \mathrm{~nm})$ time correlation. 
The TPA cross sections were calculated from slopes of the plots of $\left(1 / T(L)^{-1)}\right.$ against $I_{o}$ and $d_{o}$ by using Eq.(4).

Figure S2 shows the z-scan data for $\mathbf{1 - 3}\left(0.997 \times 10^{-3} \mathrm{M}\right.$ in THF in a $2.0 \mathrm{~mm}$ cell $)$, measured at $800 \mathrm{~nm}$ by changing the input intensity $\left(I_{o}\right)$. The corresponding data obtained by varying the dye concentration $\left(d_{o}\right)$ is shown in Figure S3. In both cases, the plots of $\left(1 / T(L)^{-1)}\right.$ vs $I_{o}$ and $d_{o}$ are linear as predicted by Eq.(4). Moreover, the TPA cross sections ( $\left.\delta_{f s}\right)$ of $\mathbf{1 - 3}$ calculated from the slopes of the both plots are very similar indicating the reliability of the measurement (see Table 2 in the text).
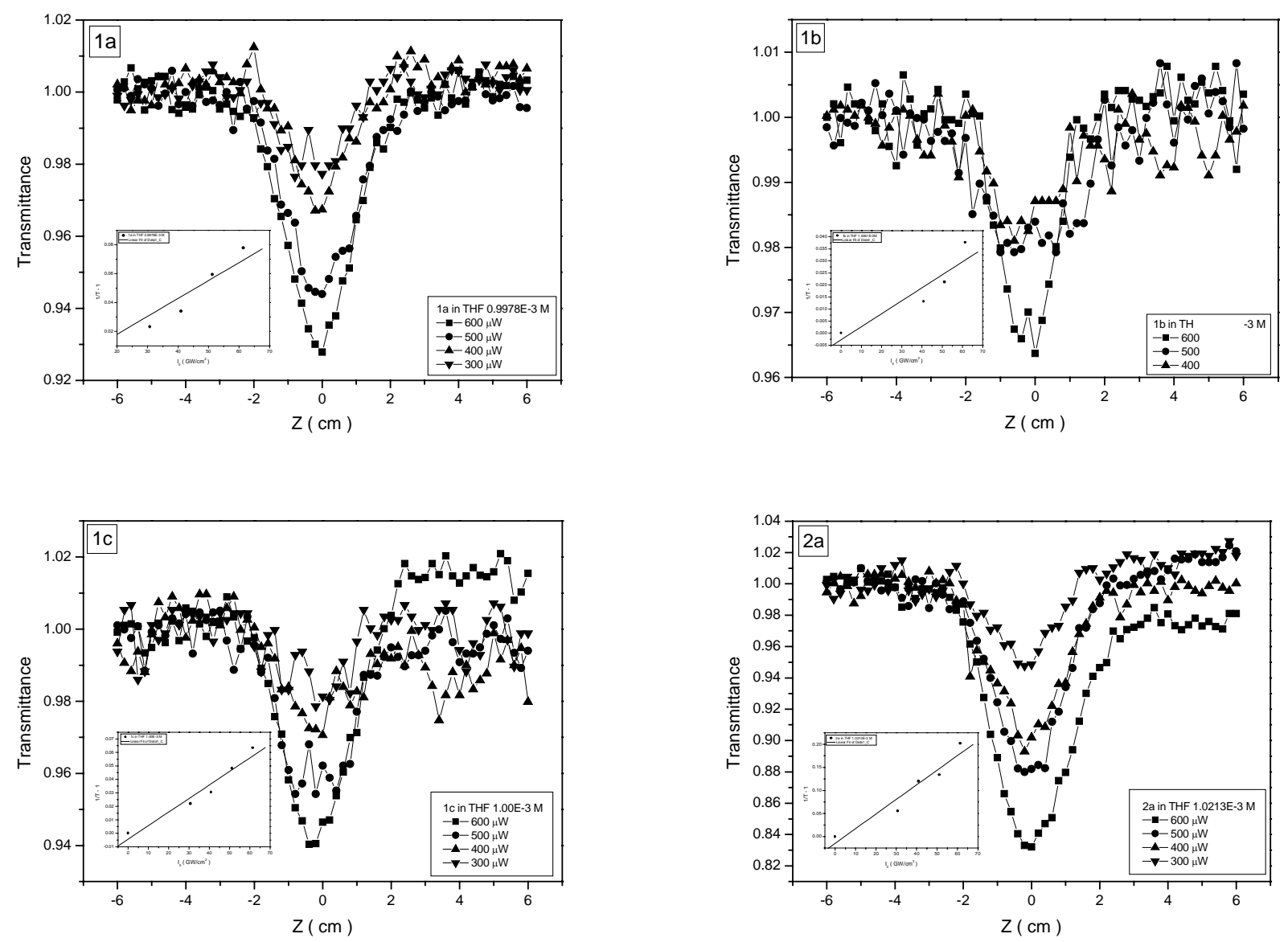

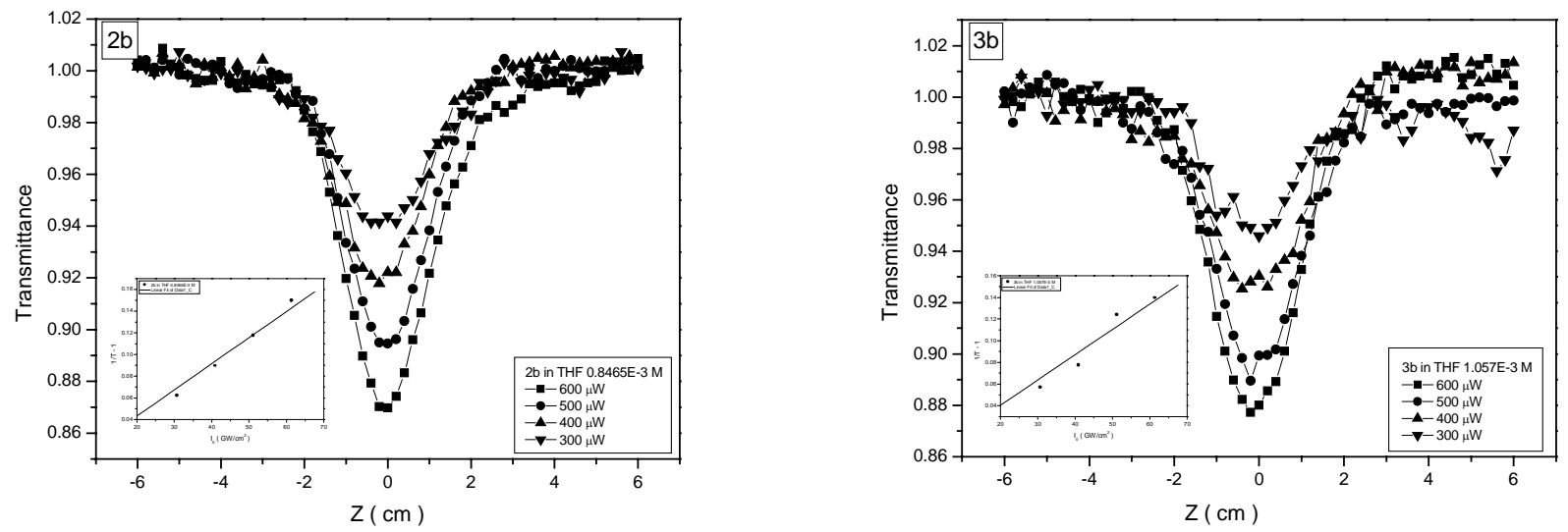

Figure S2. Z-scan experimental data for 1-3 $\left(0.997 \times 10^{-3} \mathrm{M}\right.$ in THF in a $2.0 \mathrm{~mm}$ cell $)$, measured at $800 \mathrm{~nm}$ by changing the input intensity of laser beam $\left(I_{o}\right)$. Inset: the plot of $(1 / T(L)-1)$ vs $I_{o}$ $\left(\mathrm{GW} / \mathrm{cm}^{2}\right)$.
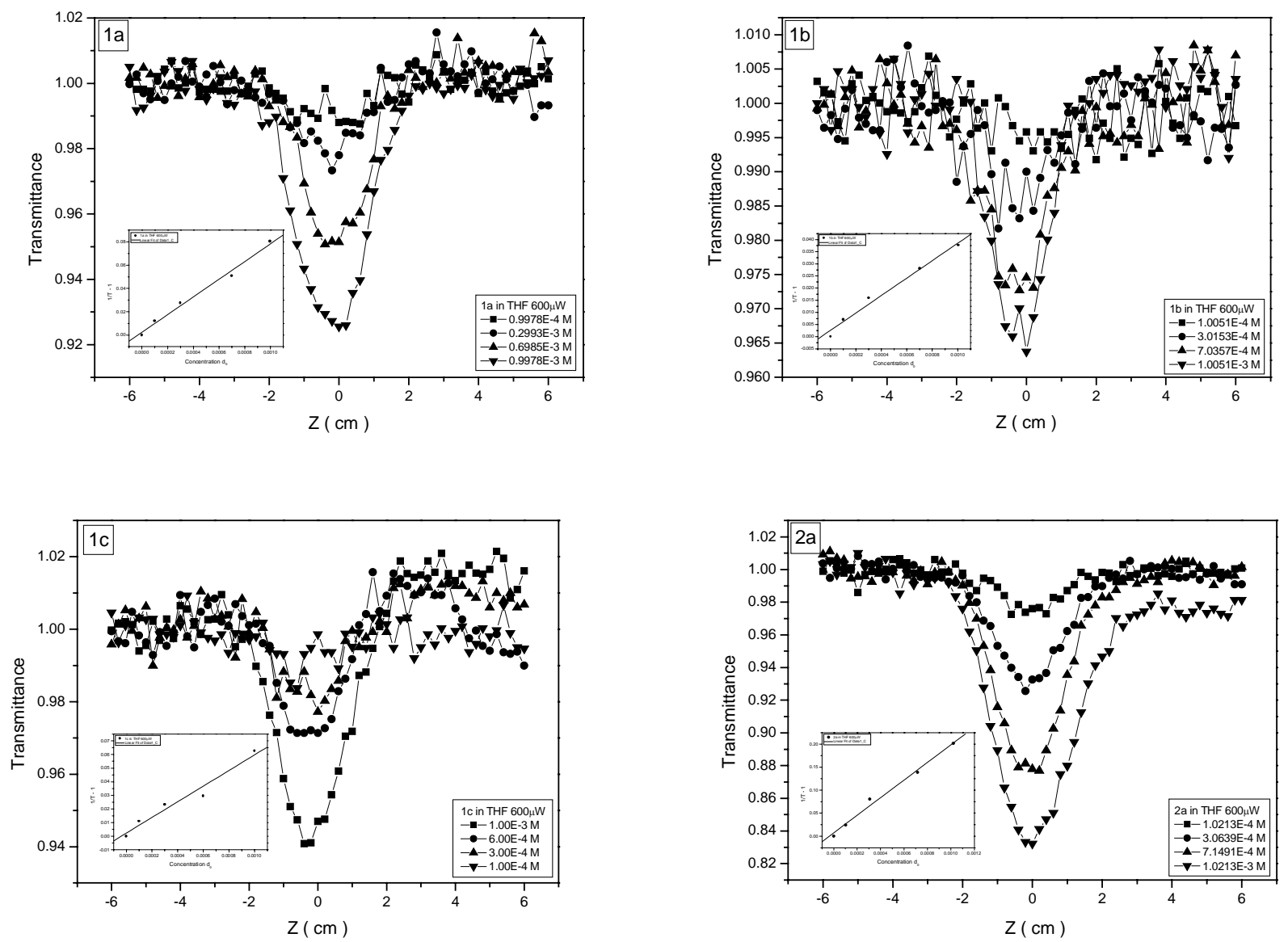

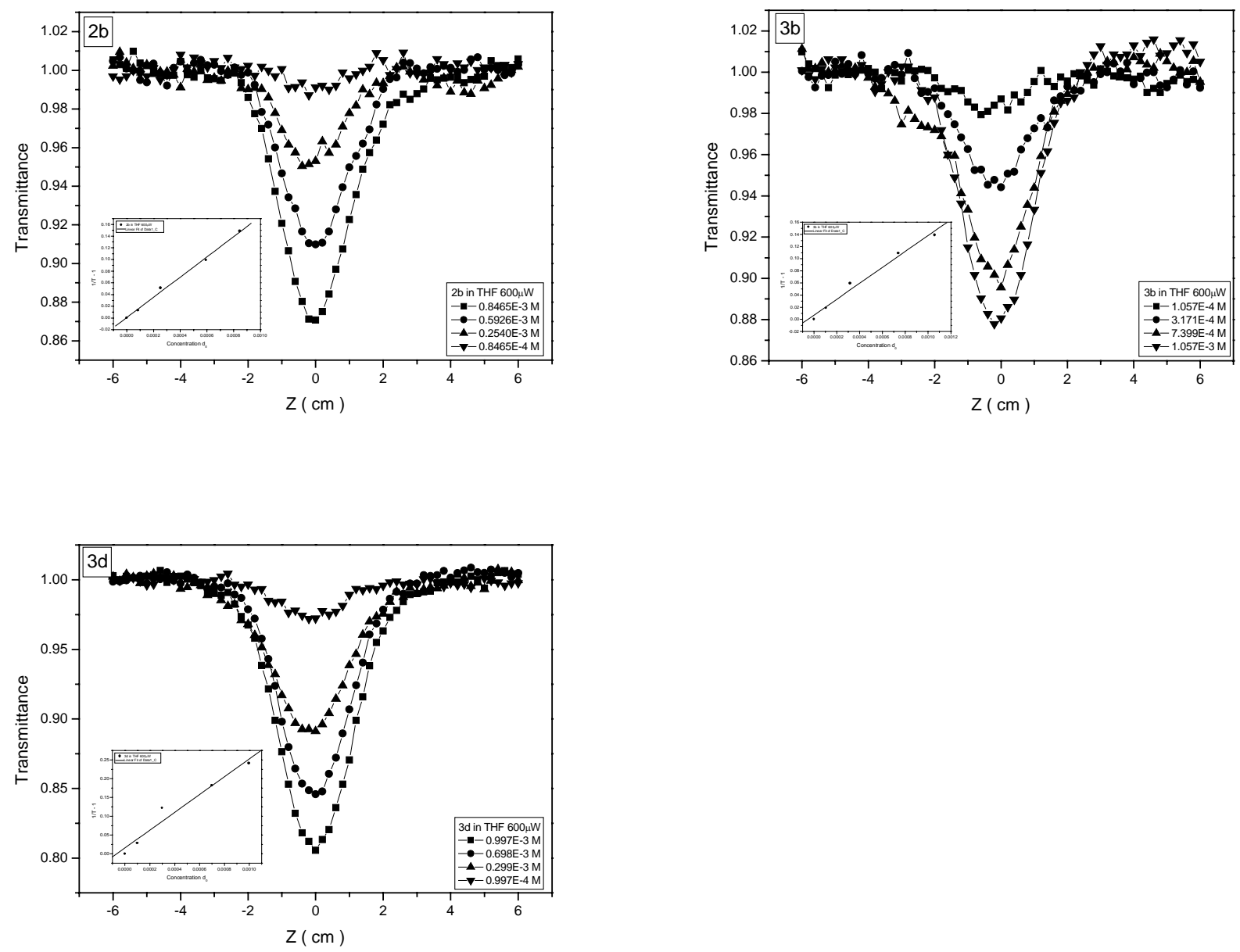

Figure S3. Z-scan experimental data for $\mathbf{1 - 3}$ in THF in a $2.0 \mathrm{~mm}$ cell obtained by varying the sample concentration. The input intensity of laser beam was $600 \mu \mathrm{W}$. Inset: the plot of $(1 / T(L)-1)$ vs $d_{o}(\mathrm{M})$.

\section{References}

(1) Chung, S.-J.; Kim, K.-S.; Lin, T.-C.; He, G. S.; Swiatkiewicz, J.; Prasad, P. N. J. Phys. Chem. B. 1999, 103, 10741.

(2) Baker, T.N.; Doherty, W. P.; Kelley, W. S.; Newmeyer, W.; Rogers, J. E.; Spalding, R. E.; Water, R. I.. J. Org. Chem. 1965, 30, 3714.

(3) An, B.-K.; Kwon, S.-K.; Jung, S.-D.; Park, S. Y. J. Am. Chem. Soc. 2002, 124, 14410.

(4) Rumi, M.; Ehrlich, J. E.; Heikal, A. A.; Perry, J. W.; Barlow, S.; Hu, Z.; McCord-Maughon, D.; Parker, T. C.; Röckel, H.; Thayumanavan, S.; Marder, S. R.; Beljonne, D.; Brédas, J.-L. J. Am. Chem. Soc. 2000, 122, 9500. 
(5) Yoo, J.; Yang, S. K.; Jeong, M.-Y.; Ahn, H. C.; Jeon, S.-J.; Cho, B. R. Org. Lett., 2003, 5, 645.

(6) Tutt, L. W.; Boggess, T. F. Prog. Quant. Electr. 1993, 17, 299.

(7) He, G. S.; Yuan, L.; Cheng, N.; Bhawalkar, J. D.; Prasad, P. N.; Brott, L. L.; Clarson, S. J.; Reinhardt, B. A. J. Opt. Soc. Am. B 1997, 14, 1079. 